\title{
Indholdsoversigt og registre over Grundtvig-Studier 1968-1987
}

ved Gustav Albeck

\section{Vejledende bemarkninger}

Angivelse af årgang er overalt trykt med kursiver, medens der til sidetallene er brugt almindelig skrift. Henvisninger til de engelske resuméer er sat i parentes.

Der er udarbejdet følgende oversigter og registre:

I Annalistisk indholdsfortegnelse.

II Forfatterregister.

Herunder: a. Register over anmeldt litteratur (ordnet alfabetisk efter forfatter, udgiver eller titel).

b. Anmelderregister

Da det ikke ses andetsteds i registrene, skal det her oplyses, at de engelske resuméer er udarbejdet af Torben Vestergaard (1970-72), Shirley Larsen (1973 og 74) og Edw. Broadbridge (1975ff) - samt William Michelsen - 